\title{
Problems of Plant Classification
}

\begin{abstract}
$\mathrm{T}^{\mathrm{H}}$ HE Masters Lectures of the Royal Horticultural Society were delivered in 1935 by Sir William Wright Smith, who chose as his subject "Problems in Classification of Plants". A very considerable field of botanical research was reviewed in the two discourses (J. Roy. Hort. Soc., 61, No. 2, 77-90 and No. 3, 117-134, February and March, 1936).

Beginning with the need of the gardener for definite names for his plants, Sir William traced the history of plant groupings. He commenced with Theophrastus, Dioscorides and Pliny, evaluated the work of Cœsalpinus, Ray and Tournefort, made suitable homage to the genius of Linnæus, and also reviewed the more recent work of Darwin, Hooker and others. A teacher of classification would there find a useful, if succinct, résumé of taxonomic history.

Sir William's deft handling of the vexed question of the subdivision or condensation of species is shown by his definition that 'a 'splitter' is one who fails to recognize that his three species are only one, as you see it, while a 'lumper' is so bold as to include in one species what you clearly see contains at least six different ones". Inequality in the application of criteria to genera was discussed, and Sir William urged that sharp and wide diversity of generic characters should have value as a possible indication of a primitive nature. The genera of the Polypetalæ, for example, stand out more distinctly from one another than do those of the less primitive. Gamo-
\end{abstract}

petalæ. The subdivision of sharply-defined primary units of classification, such as the Leguminosæ, was deprecated.

Much recent work upon intergeneric hybrids was marshalled to show that a broad concept of the genus is more in keeping with the facts presented by Nature, and no useful purpose is served by separating plants which give such adequate testimony of their affinity.

Classification must eventually stand the test of utility, either for accurate nomenclature, or as an indication of phylogeny, and to the gardener, species are almost invariably the broader concepts of Linnæus, rather than the unserviceable subordinate units of more modern tendency. The trend towards subdivision of species through natural hybridisation is greater in some parts of the world than in othersit is common in New Zealand, and rare in the Himalayas and western China. A recent analysis by Sir William and Mr. H. F. Tagg made it possible to determine the genetic constitution of several rhododendrons, and to prophesy, with some measure of success, which combinations could ultimately be found by exploration. The possible contributions of genetics to taxonomy were discussed, though it is still too early to appraise this point of view.

Sir William is, in the designation of his lectures, obviously a 'lumper', yet a 'splitter' could find no reasonable complaint in this quite impartial analysis of classification problems.

\section{Association of Teachers in Technical Institutions}

\section{Annual Conference at Plymouth}

$\mathrm{T}$ HE twenty-seventh annual conference of the Association of Teachers in Technical Institutions was held at Plymouth during Whitsuntide, when the president for 1936-37, Mr. W. T. Maccall, head of the Electrical Engineering Department, Sunderland Technical College, was inducted by the retiring president, Mr. D. W. Lloyd, principal of the Technical College, Stretford, Manchester.

In his presidential address, Mr. Maccall referred to the many new demands which the development of the petrol engine and the ever-widening use of radio and the films make upon the technical college. These demands touch nearly all departments of technical work, and range from the need for schemes of certification of garage attendants to the growing and varied courses in workshop management and production engineering.

Despite the suggestion that the art of invention is making workers into machine-minders, Mr. Maccall referred to the shortage of skilled workers, particularly in the several branches of the engineering industry. He asked how far that shortage is due to the lack of a proper recruitment policy, and how far to circumstances beyond the control of industry. Clearly a scientific age demands a scientific planning if the danger of lack of skilled workers is to be averted. Each industry must consider what type and grades of workers it requires. It should make a complete review of its methods of recruitment, conditions of service, and the normal number of its annual recruits. In proper conjunction with the local education authorities and the Board of Education, educational provision for every type of worker could be ensured. Mr. Maccall expressed the opinion that, broadly speaking, industry has not co-operated fully with education. In many cases, such full co-operation has been prevented by fear. Employers have 'feared' that technical colleges are training all to become works managers. Trade unions have 'feared' that colleges are short-circuiting apprenticeship and providing cheap labour. It should be widely known that colleges cannot make engineers, builders, etc. : they can but teach the underlying principles.

After a review of matters concerning examinations, the raising of the school-leaving age, the arguments against the multiple-bias secondary school and the possibilities of the junior technical school, Mr. Maccall referred to the relationship of the technologist to the world about him. Despite the joy which lies in seeing the applications of technology applied to the benefit of mankind, the technologist sometimes tends to lose hope when he surveys the world and sees, over 